AN ECONOMETRIC MODEL OF THE

SOVIET IRON AND STEEL INDUSTRY

Anatoli Smyshlyaev

January 1985

WP-85-5

Presented at the 5 th Task Force

Meeting on Input-Output Modeling, IIASA, October 4-6, 1984

Working Papers are interim reports on work of the International Institute for Applied systems Analysis and have received only limited review. Views or opinions expressed herein do not necessarily represent those of the Institute or of its National Member Organizations.

INTERNATIONAL INSTITUTE FOR APPLIED SYSTEMS ANALYSIS A-2361 Laxenburg, Austria 
PREFACE

Many of today's most significant socioeconomic problems, such as slower economic growth, the decline of some established industries, and shifts in patterns of foreign trade, are interor transnational in nature. But these problems manifest themselves in a variety of ways; both the intensities and the perceptions of the problems differ from one country to another, so that intercountry comparative analyses of recent historical developments are necessary. Through these analyses we attempt to identify the underlying processes of economic structural change and formulate useful hypotheses concerning future developments. Our research concentrates primarily on the empirical analysis of interregional and intertemporal economic structural change, on the sources of and constraints on economic growth, on problems arising from changing patterns of international trade, resource availability, and technology.

In writing this paper, which was presented at the last Input-Output Modeling Task Force Meeting and is therefore limited to 13 pages, I was stimulated by Dr. S. Kinoshita's research on the iron and steel industry at the world level. The purpose of this paper is to cover the development of the iron and steel industry in the USSR for the years 1960-1983 in order to find out whether its pattern is unique or rather common to any developed country. The study of this energyintensive industry furthermore contributes to the identification of the causes of slower growth in energy consumption.

Anatoli Smyshlyaev Project Leader Comparative Analysis of Economic Structure and Growth 


\title{
AN ECONOMETRIC MODEL OF THE SOVET IRON AND STEEL INDUSTRY
}

\author{
Anatoli Smyshiyaev \\ International Institute for Applied Systems Analysis, Laxenburg, \\ Austria
}

\section{INTRODUCTION}

This paper summarizes numerous econometric studies of the structure of the iron and steel industry in the Soviet Union, which have examined the demand for steel products, technological transformations within the industry, and the demand for raw materials and energy. Since there are relatively few links between this and other industries, within an input-output framework an econometric model of the steel industry can be considered as an industrial submodel that gives a comprehensive description of the structures of production and inputs. The impact of the industry on the economy as a whole is, however, very significant; its demand for energy amounts to 8\% of total national energy consumption and its high capital intensity results in a share of between $7 \%$ and $10 \%$ of gross fixed capital formation.

The Soviet iron and steel industry is one of the biggest in the world. It produces annually up to 150 million tons of crude steel and up to 120 million tons of rolled products. Its growth was generally rather stable over the period 1960-1980, although a slowdown in the production figures can be observed for 1979-1982, after crude steel production had reached a peak of 151.5 million tons in 1978. A new peak of 153 million tons was later reached in 1983.

The structure of this paper is as follows. Section 2 briefly reviews the wellknown technological processes involved in this industry and outlines the structure of the model used Section 3 presents a somewhat longer analysis of the industry's performance; Section 4, which reports some econometric results, ignoring relative prices and expressing the shares of technologies as time trends, does not go into too much detail. Finally, the conclusions indicate some important questions and show the applicability of the model.

\section{OVERVEN OF THE YODEL}

The task of the modeler is essentially the reverse of that depicted in the flowchart of the main technological processes in the iron and steel industry (Figure 1): the object is to derive, step by step, the requirements for raw materials and energy from the given demand for finished steel products.

There are two distinct but complementary ways to model transactions within the industry. One is based on "technological" parameters, for example units of pig iron per unit of steel, expressing the behavior of the industry in terms of technological progress, returns to scale, etc. The second approach is to estimate log-linear equations where a clear distinction is made between "technological" progress and increases in production; for example, pig iron used is a function of steel production.

Both approaches will possibly give the same quantitative results and both can be used in forecasting. However, in the first case one gets a clear picture of the changes in input coefficients, whether their dynamics are steady or not. Most of the ratios considered below can be interpreted as technological parameters, for example energy intensities, raw material inputs per unit of pig iron produced, while others are really shares of related products or export-import quotas. To deal with ratios is advantageous when engineering data for either the past or the future are 


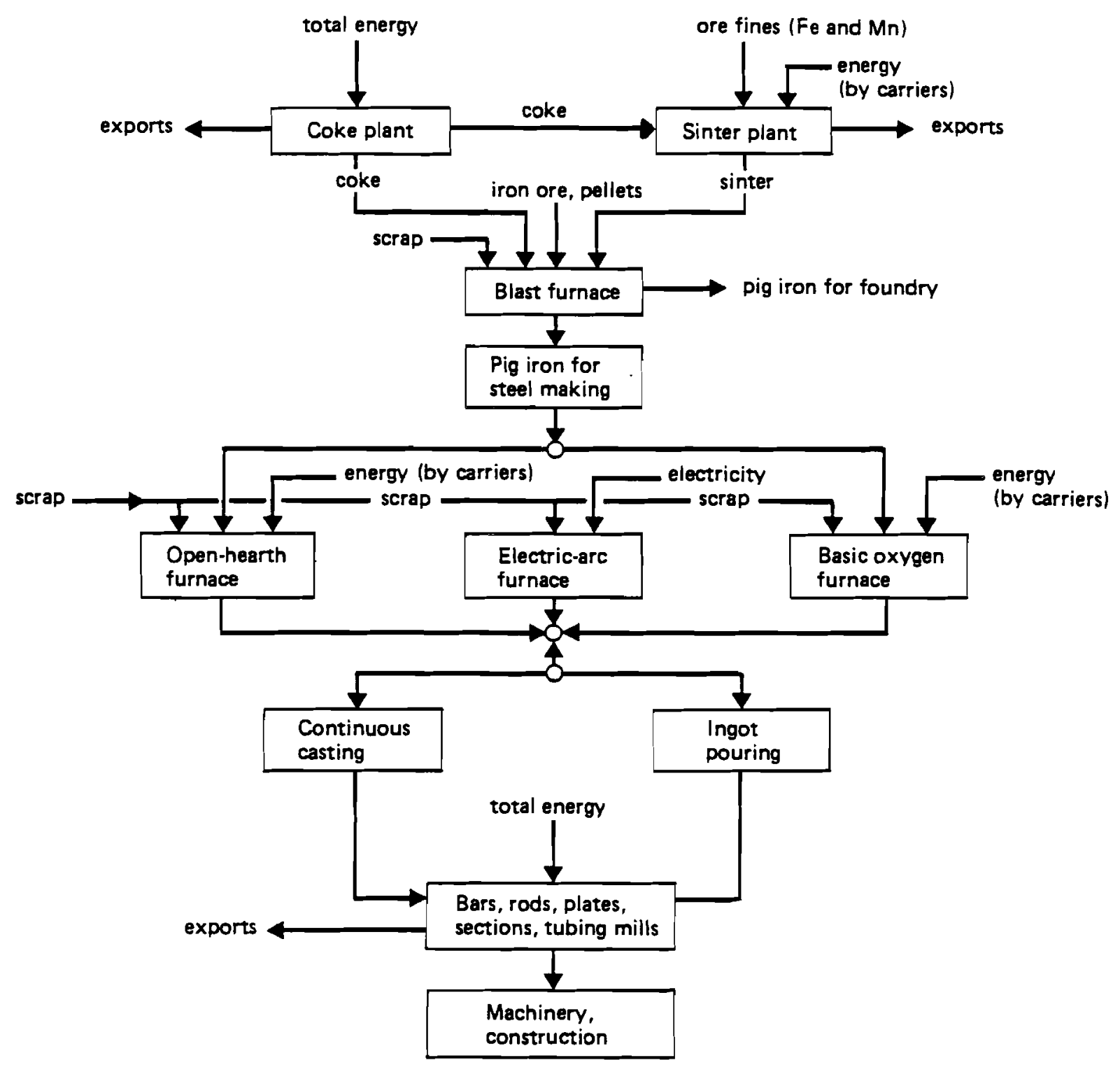

Fugure 1. Steel production processes.

involved; it is easy to replace (or to adjust) an equation by using these technological data. In contrast, when using log-linear equations, one gets a set of elasticities and, in a reduced form of a model, a clear picture of the differences in rates of growth for different products (both inputs and outputs) with respect to the growth of demand for end-use rolled products.

A simplified flow-chart of the model looks as follows:

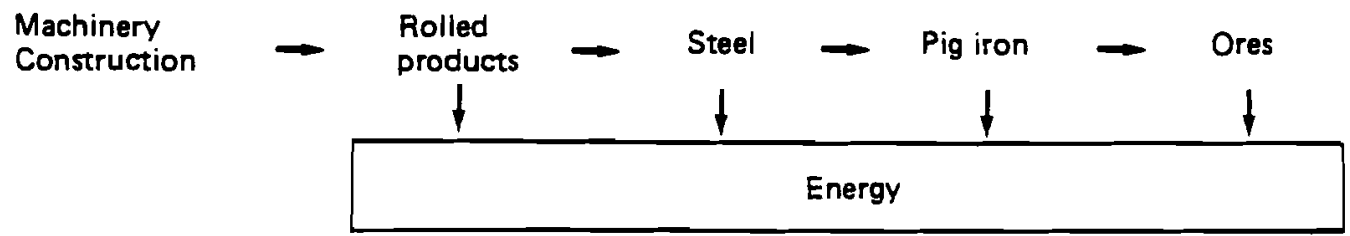


One of the most important questions related to this model is the estimation of energy demand, which is rising more rapidly than any of the production figures expressed in physical units. Table 1 presents some details. The energy used by the iron and steel industry in 1982 is estimated to have been approximately 6370 GJ, or about $7.1 \%$ of total energy demand, as compared to $8.6 \%$ in 1970 and $8.1 \%$ in 1975.

TABLE 1 Energy consumption (GJ) in the Soviet iron and steel industry, 1963-1980.

\begin{tabular}{lcccc}
\hline \hline & 1963 & 1970 & 1975 & 1980 \\
\hline Iron and steel industry & 2240 & 3507 & 4378 & 4785 \\
Percentage per ton of: & & & & \\
Rolled products & 42.2 & 43.6 & 46.6 & 46.4 \\
Crude steel & 28.4 & 30.3 & 31.1 & 32.1 \\
Pig iron & 39.0 & 41.0 & 42.8 & 44.5 \\
\hline \hline
\end{tabular}

The structure of energy inputs (Table 2) is changing in favor of natural gas and electricity, while the share of coal dropped from $52 \%$ in 1970 to $43.5 \%$ in 1980 . Thus, the various developments in energy conservation related to each process (ECE, 1983) overshadowed the other effects, namely the required increase in the quality of end products and/or product-mix effects.

TABLE 2 The structure (percentage shares) of net energy consumption in the Soviet Union, 1970-1980.

\begin{tabular}{lrrr}
\hline \hline Energy carrier & 1970 & 1975 & 1980 \\
\hline Coal & 51.7 & 47.2 & 43.5 \\
Oil & 5.0 & 5.5 & 5.1 \\
Natural gas & 31.5 & 34.3 & 36.1 \\
Electricity & 11.8 & 13.1 & 15.3 \\
\hline \hline
\end{tabular}

Within the Soviet iron and steel industry, the bulk of the energy requirement (about 45\%) goes into pig-iron production; $13 \%$ is used in agglomeration processes and coke production, while the last stage, rolling, accounts for between $10 \%$ and $12 \%$.

$a$

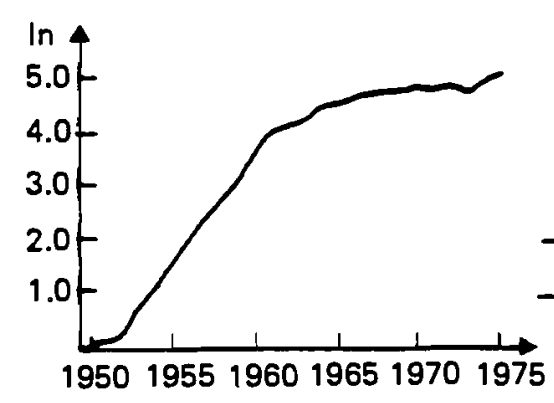

$b$

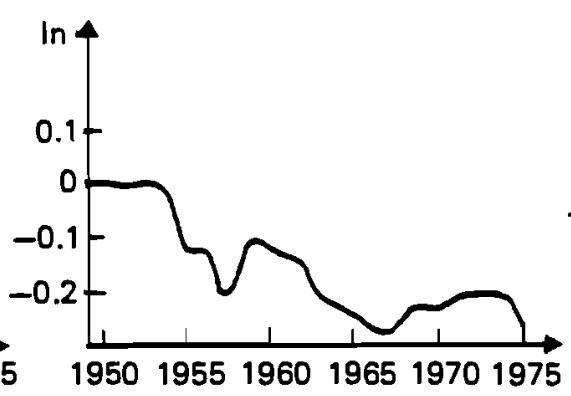

$c$

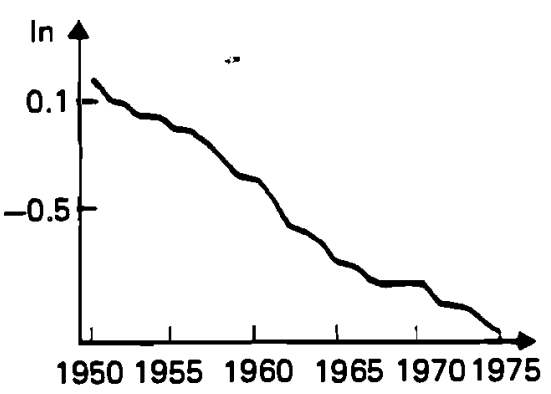

Figure 2. Changes in the inputs of various energy carriers per unit output of the Soviet iron and steel industry, 1950-1975: $a$, natural gas; $b$, oil; $c$, coal.

It is not immediately obvious whether the breakdown of iron and steel production figures into distinct processes, followed by a stage-by-stage analysis, is any more valuable than a macroeconomic consideration of the input and output structures of the industry as a whole. For example, why not relate energy consumption 


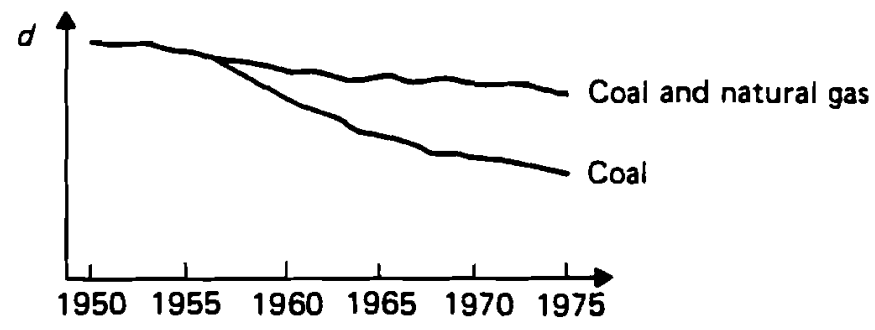

Figure 3. Share of various energy carriers in the energy consumption of the Soviet iron and steel industry, 1950-1975.

to the volume of finished steel products? Raw material inputs are relatively trivial, so that such a breakdown still would not link an industry model effectively with other branches of the economy.

The "common sense" argument in favor of the stage-by-stage approach is that the information obtained is valuable in itself, since it helps to identify possible structural shifts in the industry's development. In other words, technological parameters for the industry as a whole may reflect to a marked extent the impacts of product- (or technology-) mix effects, which cannot be studied at the macro level.

One example is the demand for coal. Analysis of the stage-by-stage utilization of coal by the iron and steel industry gives us a fairly clear picture of the expected demand for the bulk of coal deliveries, because this bears rather fixed proportions to the production of pig iron, coke, and sinter. But it also implies knowledge of the distribution of coke between different processes and outside consumers. An attempt to explain coke demand in terms of pig iron production assumes a regular relationship between total pig iron production and the proportion used for steel-making, while this ratio is actually constantly changing. Just replacing the unknown aggregate demand by an unknown structure does not take us much further.

We could relate coal demand to end products but the mixture of technologies involved might lead to instability in the "technical" parameters. The incorporation of too many secondary effects would transform the technological relations into a rather weak econometric model. This approach would also imply a fixed proportion of steel produced from scrap, while the share of the electric-arc process in fact varies over time.

The demand for different energy carriers has developed irregularly over the period studied, as shown in Figure 2. Substitution effects have also varied widely within the iron and steel industry as a whole, since different processes have different energy intensities and very different energy-input structures.

Note that here we include in the iron and steel industry a number of specialized plants, as well as the category known as "minor metallurgy," which consists of specialized parts of machinery plants. Including pig iron for foundries and steel castings is more questionable, because the bulk of pig iron for foundries is produced outside the specialized plants, largely from scrap from pig iron deliveries. The remainder of the pig iron produced within the industry is used for tubes and the basic installations needed to produce steel and rolled products, and in this case it is accounted as having been used by the industry itself after amortization.

The share of steel for castings produced by the industry is relatively small.

With one exception, the intermediate products of the iron and steel industry are used within the industry itself or else are exported; the exception is coke, which 
is also delivered to other branches of the economy.

\section{DATA SOURCES AND OBSERVED TRENDS}

Three main sources ("Narkhoz," "CMEA," and "UN") were used for the period 1960-1982. These are complementary in many respects. For example, data on the total production of crude steel are available in Narkhoz and CMEA. whereas these sources only report the steel produced by different processes (oxygen. Martin process, electric arc) in the case of steel produced in specialized plants. In contrast, UN gives crude steel production by type of process for steel production as a whole. CMEA adds to the data in Narkhoz some information on pig iron production for steel making, while Narkhoz provides additional information on the qualities (i.e. metal content) of the iron and manganese ores used.

All of these data originate from the USSR Statistical Board, so that there is very little risk of methodological discrepancies in utilizing and combining data from different publications. In addition to the three major sources, we have also used data from the ECE study "Strategy for Energy Use in the Iron and Steel Industry" (referred to as "ECE") and a number of papers published in recent years in Russian.

\subsection{Wining and Preprocessing}

This stage covers coke production, iron and manganese ore mining, and the production of sinter and pellets. The requirements here are mostly on the capital side, but energy inputs (specifically, coal for coke, electricity, and coke breeze for agglomerates) are also considered.

The production of iron ore is represented by three variables: iron ore mined (fercr), i.e. the weight of crude ore, iron ore shipped (ferore), and the shipped content of iron ore expressed as the percentage metal content ( $f$ er \%); Table 3 shows the development of these variables over the period 1960-1980.

TABLE 3 Soviet iron ore production, 1960-1980.

\begin{tabular}{lrrrr}
\hline \hline & 1960 & 1970 & 1975 & 1980 \\
\hline fercr (million tons) & 141.55 & 355.36 & 441.79 & 498.13 \\
ferore (million tons) & 105.86 & 195.49 & 232.80 & 244.76 \\
fer\% & 54.08 & 106.46 & 127.94 & 132.89 \\
& & & & \\
ferore/fercr & 0.75 & 0.55 & 0.53 & 0.49 \\
fer\%/ferore & 0.51 & 0.54 & 0.54 & 0.54 \\
fer\%/fercr & 0.38 & 0.30 & 0.29 & 0.27 \\
\hline
\end{tabular}

Two of the ratios in Table 3 (ferore/fercr, fer\%/fercr) show a further decline in the "quality" of iron ores since 1970; this was after the most significant changes between mined and shipped ores had taken place between 1960 and 1970 . But the continuous decline in these ratios may also partially explain the supply rigidities and the possible increase in investment requirements. Another indicator is also of interest: the shares of iron ore shipped in the form of concentrates or as mined, respectively (see Table 4). The latter share decreased from $44.8 \%$ in 1966 to $30.9 \%$ in 1978 and to $25.9 \%$ by 1982 . This reflects the fact that "high quality" iron ore, which can be shipped in the form in which it is mined, has decreased not only relatively but also in absolute terms from 85.7 million tons in 1976 to 63.2 million tons in 1982, after having earlier grown from a level of 72.7 million tons in 1966. The ratio between iron ore mined and iron ore shipped from the mines as concentrates increased by 20\% from 1966 to 1982; i.e. in 1966, 2.1 tons of iron ore mined were transformed at source for every ton shipped as concentrates, while in 1982 , 
2.45 tons of crude iron ore were required for every ton of concentrates shipped.

TABLE 4 Iron ore and concentrates shipped in the Soviet Union, 1966-1982.

\begin{tabular}{lrrrr}
\hline \hline Category shipped & 1966 & 1976 & 1980 & 1982 \\
\hline Total & 160.3 & 241.2 & 244.8 & 244.4 \\
As concentrates & 88.6 & 155.5 & 176.6 & 181.2 \\
As mined & 71.7 & 85.7 & 68.2 & 63.2 \\
\hline \hline
\end{tabular}

The production of manganese ore did not increase as fast as that of iron ore; manganese ore shipments (mnore) took nearly 23 years to double, while the manganese metal content ( $\mathrm{mn} \%$ ) did not decrease so much as the metal content of iron ore, although a decline was noted between 1975 (35\%) and 1980 (31\%). The greater part of total manganese ore production during the period went for export.

It is important to note that the metal content of both kinds of ores stabilized in 1970-1975 before dropping later.

Developments in the production of two kinds of agglomerates (sinter and pellets) differed significantly. The production of pellets was almost zero in the early 1960 s and grew to 55 million tons by 1982 , while sinter production grew steadily from 65 to 150 million tons over the same period, as shown in Table 5.

TABLE 5 Production of agglomerates in the Soviet iron and steel industry, $1960-1980$.

\begin{tabular}{lcrrrr}
\hline \hline & 1960 & 1966 & 1970 & 1975 & 1880 \\
\hline Sinter & 65.1 & 115.7 & 138.2 & 151.9 & 153.8 \\
Pellets & - & 1.6 & 10.6 & 27.2 & 50.9 \\
\hline \hline
\end{tabular}

The growth of coke production (coke) was steady, at about $2.5 \%$ per annum during the period studied. The share of exports (excoke) increased in the 1960 s before stabilizing in the 1970s; imports of coke (imcoke) remained relatively constant.

Expressing the energy inputs needed for coke production in terms of tons of coal equivalent (tce), we find that they correspond to approximately $10 \%$ of the total production of coke. We examined the effects of changes in this percentage on the basis of Pavlenko and Tichomirov's (1983) assertion that a $1 \%$ change would be equivalent to 7 million tce in 1960 and 8 million tce in 1980. We have used the available figures for coke production and its consumption in pig iron production, together with "technological" parameters from ECE and from Pavlenko and Tichomirov (1983).

The demand for coke breeze in agglomeration is estimated to have been 3.3 million tons in 1960 and 6.5 million tons in 1980 . It can also be observed that there has been a significant substitution of coke breeze by natural gas, whose share grew 1.5 times over the decade 1970-1980, while the total energy requirement per ton of agglomerate dropped by $10 \%$ over the same period.

\subsection{Pig Iron Production}

The domestic demand for iron ore, sinter, and pellets was derived with the help of "engineering" data, together with data (UN) on the consumption of iron ores (feroc), agglomerates (sinoc,peloc), and total ores (oreoc). Trends in the consumption of these raw materials are shown in Table 6.

Due to the internal changes in the structure of agglomerate, we obtain an unstable "technological" parameter (oreoc/pig), which is 1.775 for 1965 and 1975 and 1.8 for 1970 and 1980 . It is clear that every component of this parameter was 
TABLE 6 Raw material inputs (million tons) in pig iron production in the Soviet Union, $1960-1980$.

\begin{tabular}{lccccr}
\hline & 1960 & 1966 & 1970 & 1975 & 1980 \\
\hline pig & 46.76 & 70.26 & 85.93 & 102.97 & 107.28 \\
oreoc & 87.49 & 128.9 & 154.94 & 182.79 & 194.41 \\
of which: & & & & & \\
feroc & 23.66 & 17.44 & 11.43 & 12.57 & 8.90 \\
sinoc & 63.83 & 109.86 & 132.92 & 143.03 & 143.31 \\
peloc & 0.00 & 1.61 & 10.62 & 27.20 & 42.20 \\
creoc/pig & 1.871 & 1.775 & 1.803 & 1.775 & 1.812 \\
feroc/pig & 0.506 & 0.248 & 0.133 & 0.122 & 0.083 \\
sinoc/pig & 1.365 & 1.564 & 1.547 & 1.389 & 1.336 \\
peloc/pig & 0.000 & 0.023 & 0.124 & 0.264 & 0.393 \\
(sinoc +peloc)/pig & 1.365 & 1.589 & 1.671 & 1.653 & 1.729 \\
\hline \hline
\end{tabular}

increasing or decreasing smoothly. When we take into account the fact that the "quality" of iron ore mined remained rather stable between 1970 and 1975, we can also explain the very slow process of iron ore "substitution" over the same period that its consumption increased from 11.43 to 12.57 million tons. The significant slowdown in 1975-1980 can be ascribed to the (possibly forced) substitution brought about by the lower quality of iron ore mined.

In the last ten years, the consumption of coke in blast furnaces (cokeocp) has decreased significantly in relative terms, mainly due to its substitution (directly and indirectly) by natural gas. The share of pig iron produced using natural gas increased from $\mathbf{7 8 \%}$ in 1965 to $\mathbf{8 3 \%}$ in 1980.*

TABLE 7 Energy inputs in pig iron production in the Soviet Union, 1960-1980.

\begin{tabular}{lcccrr}
\hline & 1960 & 1966 & 1970 & 1975 & 1980 \\
\hline pig & 46.76 & 70.26 & 85.93 & 102.87 & 107.20 \\
cokeocp & 33.85 & 43.31 & 49.24 & 56.23 & 57.80 \\
cokeocp/pig & 0.724 & 0.616 & 0.573 & 0.546 & 0.540 \\
cokeocp/energyoc & - & - & 0.730 & 0.720 & 0.710 \\
\hline \hline
\end{tabular}

Demand for scrap is easy to estimate after we subdivide the pig iron production figures into their two major components - pig iron for steel making (pigosm) and pig iron for foundries (pigof) - whose growth behavior differs significantly. Since the scrap consumption per ton differs by a factor of ten for these two processes, "technological" parameters are best quoted separately for each: scraposm fell from 0.021 in 1966 to 0.015 in 1975 , while scrapof rose from 0.108 to 0.125 over the same period. Pig iron for foundries reached a peak of 9 million tons in early 1970 and then dropped steadily over the years, while pig iron for steel making reached a peak of 102.5 million tons in 1978. Thus, the slowdown of total pig iron production in 1978-1982 must be divided into two parts - a continuous secular slowdown (which accelerated in the late 1970s) in pig iron for foundries and a more recent slowdown in pig iron for steel making. Other minor components included in total pig iron

\footnotetext{
- Observe that one cubic meter of netural gas substitutes $0.8-0.8 \mathrm{~kg}$ of coke in pig iron production. Thus. if the major part of the slowdown in coke input (from 0.72 tons per ton of pig iron in 1880 to 0.54 tons per ton in 1880) has been due to this substitution, then we can estimate natural ges consumption as being in the region of 10 billion cubic meters.
} 
production, such as ferromanganese and "spiegel" pig iron, have also steadily decreased since 1970 , so that by $1980,93 \%$ of total pig iron production went into steel making.

\subsection{Steel Making}

Steel production figures on average bear a close relation to the growth of pig iron production; their rates of growth (3.8\% per annum over the period 1961-1982) essentially do not differ. Crude steel production increased from 65.3 million tons in 1960 to a peak of 151.5 million tons in 1978 , before dropping to 147.2 million tons in 1982. The relationship between the two time series can be seen in Table 8 . Another ingredient for steel making is scrap, of which 55 million tons was consumed in 1966. In the manufacture of steel, 0.57 tons of scrap are used per ton of steel as compared with 0.62 tons of pig iron.

TABLE 8 Steel production (million tons) and its relation to pig iron production in the Soviet Union, 1960-1982.

\begin{tabular}{lcccccr}
\hline \hline & 1960 & 1965 & 1970 & 1975 & 1980 & 1982 \\
\hline steel & 65.3 & 91.0 & 115.9 & 141.3 & 147.9 & 147.2 \\
steel/pig & 1.40 & 1.38 & 1.35 & 1.37 & 1.38 & 1.38 \\
steel/pigosm & 1.70 & 1.62 & 1.53 & 1.51 & 1.48 & 1.48 \\
\hline \hline
\end{tabular}

No further analysis of the steel making process can be pursued without breaking down the steel production figures into three main processes, each of them very different in terms of raw material and energy demand Between them, the oxygen converter (oxy), open-hearth (martin), and electric-arc (elec) processes account for over 97\% of Soviet steel production, with the remainder being produced using the Bessemer process. The changing structure of steel production can be seen from Table 9. The share of martin steel went down steadily from $84 \%$ to $60 \%$ over the period studied, and it was replaced by oxy steel, whose share grew from $4 \%$ to $28 \%$ over the same period. But what is more important is that the share of elec steel remained relatively constant over time. This pattern is very different from that in other developed countries, where the electric-arc process generally has a much larger share.

TABLE 9 Structure of Soviet steel production, 1960-1979.

\begin{tabular}{lccccc}
\hline \hline & 1960 & 1965 & 1970 & 1975 & 1979 \\
\hline oxy & 2.5 & 4.0 & 19.9 & 34.8 & 42.3 \\
martin & 55.1 & 75.9 & 84.1 & 91.5 & 91.1 \\
elec & 5.8 & 8.5 & 10.7 & 14.0 & 14.9 \\
oxy/steel & 0.04 & 0.04 & 0.17 & 0.25 & 0.28 \\
martin/steel & 0.84 & 0.83 & 0.73 & 0.65 & 0.60 \\
elec/steel & 0.09 & 0.10 & 0.09 & 0.09 & 0.10 \\
\hline \hline
\end{tabular}

The differences in the input structure for the different types of steel are summarized in Table 10.

Simple calculations show that about $80 \%$ of the decrease in energy input per ton of steel was due to structural shifts in technology mix, with the rest being due to increased energy efflciency within each technology. For example, natural gas requirements for the open-hearth process were 5 billion cubic meters in 1966 and increased by $20 \%$ to 6 billion cubic meters by 1980, due to a combination of effliency increases and the slow growth of martin steel; the corresponding 
TABLE 10 Structure of inputs per ton of steel produced by various processes in the Soviet Union, 1980.

\begin{tabular}{lcccc}
\hline \hline Process & \multicolumn{2}{c}{ Input } & & \multicolumn{2}{c}{ Percentage share } \\
\cline { 2 - 5 } & $\begin{array}{c}\text { Pig iron } \\
\text { (tons) }\end{array}$ & $\begin{array}{c}\text { Energy } \\
\text { (GJ) }\end{array}$ & Electricity & $\begin{array}{c}\text { Natural } \\
\text { gas }\end{array}$ \\
\hline oxy & 0.880 & 0.84 & 33.3 & 66.7 \\
martin & 0.580 & 4.05 & 1.4 & 37.9 \\
electric & 0.033 & 6.97 & 87.2 & 10.6 \\
\hline \hline
\end{tabular}

technical parameters were 0.069 in 1966 and 0.066 in 1980. The share of natural gas in energy input increased over the same period from less than $50 \%$ to $60 \%$.

To complete the picture it should be noted that some steel is also produced outside the iron and steel industry as defined here. The amounts involved are relatively small but there are large proportional variations from one process to another. Electric arc steel produced outside the industry increased threefold in amount from 1960 to 1980 , while the outside contribution to martin steel production remained small and relatively constant.

Of particular interest is the continuous casting process, which is heavily reliant on technological advance; in the Soviet Union it accounts for only $10 \%$ of all steel produced, which is significantly lower than in other developed countries.

\subsection{Finished Steel Products}

At least 20 end products may be identified, but these are aggregated here into two main groups: plates (including tubes and ingots) and sections. The shares of sections and plates in total finished rolled products (rolf) have changed very smoothly over time, as shown in Table 11.

TABLE 11 Structure of rolled steel products produced in the Soviet Union, $1960-1980$.

\begin{tabular}{lrrrrc}
\hline & 1960 & 1965 & 1970 & 1975 & 1980 \\
\hline sections & 29.02 & 38.09 & 49.51 & 58.55 & 59.4 \\
plates & 14.08 & 23.02 & 30.54 & 39.35 & 42.7 \\
sections/rolf & 0.66 & 0.62 & 0.61 & 0.59 & 0.58 \\
plates/rolf & 0.32 & 0.37 & 0.38 & 0.40 & 0.42 \\
\hline \hline
\end{tabular}

The absolute level of tube production did not decrease in the late 1970s and a peak of 18.2 million tons was reached in 1979; however, the rate of growth declined between 1977 and 1983, as shown in the 1983 level of 18.7 million tons.

Total energy requirements for rolling mills account for only $12 \%$ of total energy use in the iron and steel industry. Approximately half of the direct energy input is secondary energy derived from other processes in the industry. The bulk of the net energy consumption is supplied by natural gas and electricity (up to 15 billion kWh).

\subsection{The Use of Eind Products}

The bulk of the end products of the Soviet iron and steel industry are destined for the machinery and construction sectors, which themselves contribute significantly to investment. Among the machinery-sector industries, some use metal products intensively (e.g. metallurgical equipment, metal structures, transport equipment) while others do not rely so heavily on rolled steel products (e.g. electrical appliances). Average rates of growth in machinery have been 
considerably higher than that of iron and steel end- product production, with the slowest growth being recorded by those industries closely connected to investment formation. The elasticities of the growth of individual industries (given below in parentheses) with respect to that of the machinery sector as a whole over the period 1965-1980 reveal three main groups: low growth was observed for forging $(0.44)$, bearings $(0.45)$, metallurgical and boring equipment $(0.50)$, railway equipment (0.52), energy equipment (0.58), transport equipment (0.59), food and lighting equipment (0.67); the average group included autos (1.0), tools (0.85), chemical equipment $(0.78)$, building equipment $(0.74)$, metal structures $(0.74)$, repairs $(0.72)$, and electrotechnology (0.70); the single high growth industry was electrical appliances and devices (2.3).

The share of equipment in gross fixed capital formation grew approximately fivefold in 20 years, from 11.2 billion roubles in 1960 to 50.2 billion roubles in 1980; over the same period the ratio between equipment investment and the production of finished rolled products (expressed in billion roubles per million tons) rose from 0.27 in 1960 to 0.48 in 1980.

To model the demand for end products we can use the 1972 Soviet input-output data as a system of weights and then relate the growth in end products to machinery and construction, assuming an average rate of technological progress (in terms of metal saved per rouble of output). Alternatively, we could use an aggregated index for machinery and construction, and rely on the trends reported by Yaremenko (1981) for the products of the iron and steel industry expressed in value terms.

\section{ECONOMETRIC RESULTS}

In general, two types of equations have been estimated, "technical" equations and time-trend equations. Time trends for technical coefficients have been estimated in both linear and exponential form. It has also been found valuable to estimate the relationships between different inputs, such as the substitution of coke in pig iron production by natural gas.

The fast and relatively steady growth of all economic indicators over the period 1960-1982 led to a high level of significance in the parameter estimates for the second set of equations; therefore we do not report here standard goodness-of-fit characteristics except for those equations in which the slope coefficients or the time-trend parameters are insignificant. Due to colinearity between the time variable and the explanatory variables we have sometimes chosen the simplest form, omitting time trends.

We also examined carefully the development of various technical parameters, some of which have exhibited strong and consistent time trends and others that appear to have made "U-turns" in recent years.

The flow-chart on the next page shows aggregate-level elasticities $(\varepsilon)$ of the demands for semi-finished and raw material inputs, together with estimates $r$ of the time trends or residual technological-progress and product-mix effects.

The next two subsections present details of the regression analysis. Note that for pig iron production there have been important substitutions not only between energy carriers but between materials: this is illustrated by the last three regressions in Section 4.2, and has caused significant changes elsewhere in the structure of the industry. 


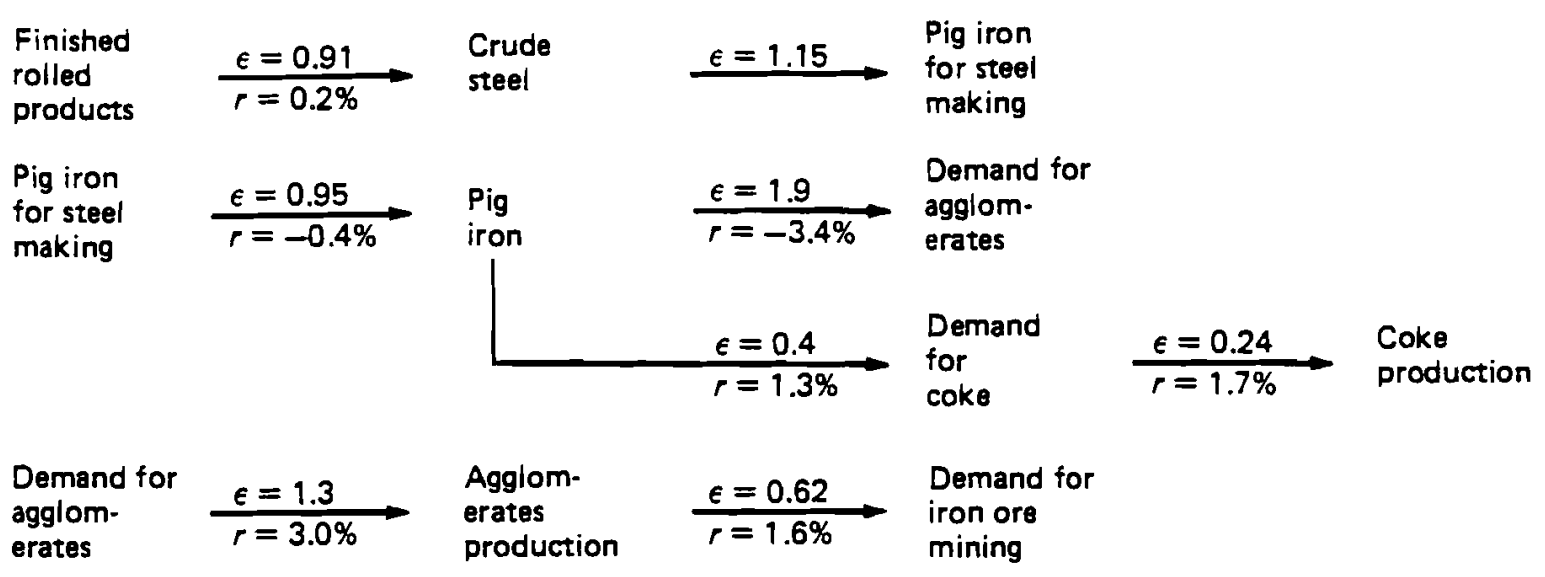

\subsection{Technical Parameters and Shares}

$$
\begin{aligned}
& \text { steel } / \text { rolf }=1.49-0.0037 t \\
& \text { pigosm } / \text { steel }=0.586+0.0050 t \\
& \text { pig } / \text { pigosm }=1.234-0.0084 t \\
& \text { sinteroc } / \text { pig }=1.4508+0.0172 t \\
& (\text { sinter }+ \text { pell }) / \text { sinoc }=1.054-0.0012 t \\
& \text { ferore } /(\text { sinter }+ \text { pell })=1.4043-0.0079 t
\end{aligned}
$$

\subsection{Relationships Between Physical Indicators}

The following regression equations are logarithmic and t-values are given in parentheses:

$$
\begin{aligned}
& \text { steel }=0.755+0.907 \text { rolf }+0.002 t \\
& \text { (77.3) (4.0) } \\
& \text { pigosm }=-1.14+1.144 \text { steel }+0.0014 t \\
& \text { (54.1) (1.6) } \\
& \text { pigosm }=-1.279+1.177 \text { steel } \\
& \text { (188.6) } \\
& \text { pigom }=-0.587+1.007 \text { martin }+0.01 t \\
& \text { (11.4) }(0.4) \\
& \text { pigom }=-0.697+-11.034 \text { martin } \\
& \text { (36.0) } \\
& \text { scrapom }=-0.100+0.843 \text { martin }+0.006 t \\
& p i g=0.411+0.946 \text { pigosm }-0.004 t \\
& \text { (58.0) }
\end{aligned}
$$




$$
\begin{aligned}
& \text { cokeoc }=1.916+0.411 \mathrm{prg}+0.13 \mathrm{t} \\
& \text { (4.3) (2.7) } \\
& \text { coke }=3.186+0.244 \text { cokeoc }+0.272 t \\
& \text { (0.9) (1.8) } \\
& \text { coke }=1.442+0.742 \text { cokeoc } \\
& \text { (23.5) } \\
& \text { sinoc }=-2.964+1.862 \text { pig }-0.033 t \\
& \text { (15.1) (5.2) } \\
& \text { sinter }=-1.178+1.297 \text { sinoc }-0.030 t \\
& \text { (17.4) (6.3) } \\
& \text { ferore }=2.065+0.616 \text { sinter }+0.016 t \\
& \text { (13.2) (8.9) } \\
& p i g=4.744+0.685 \sin 0 c+1.033 \text { peloc }-1.83 t \\
& \text { (1.0) (7.6) (4.3) (2.1) } \\
& \text { pig }=0.771 \text { sinoc }+1.232 \text { peloc }-2.62 t \\
& \text { (39.8) (9.3) (6.9) } \\
& \text { sinoc } / \text { pig }=1.332-2.51 \text { (peloc } / \text { pig })+0.047 t \\
& \text { (52.6) (9.6) (8.3) }
\end{aligned}
$$

\section{CONCLUSIONS}

Our study of the historical development of the Soviet iron and steel industry over the last twenty years has highlighted the need for a joint consideration of technical coefflcients and the shares of different technologies and products. Very marked overall shifts in energy and raw-material requirements can arise from processes of substitution that are intrinsically relatively stable, and the growth in some products necessarily takes place at the expense of others.

A stage-by-stage analysis of the technological transformations and energy requirements of the industry showed that steel produced by the oxygen convertor process requires $2-2.5$ times as much energy per ton as electric-arc steel. Using this and other weighting information, together with various time series of total energy use in the iron and steel industry, we developed an econometric model that takes into account product-mix effects and energy-saving processes at each stage of production. Detailed regressions were reported for a number of parameters of particular interest.

Technological progress, particularly that of an energy-saving nature, clearly plays a major role at all stages of production. Nevertheless, the growing demand for high-quality end products has been responsible for increases in the demand for primary inputs, both raw material and energy, which have to a certain extent cancelled out the energy savings achieved technically.

As pointed out by Gladyshevski et al. (1980), the slowdown in the growth of finished steel products has led to adaptation elsewhere in Soviet industry through three mechanisms: a slowdown in other metal-intensive industries; substitution of iron and steel products by other materials; and more rapid price increases (or price 
rises without any corresponding improvement in quality) for products like machinery with a high metal content.

Finally, Narkhoz has provided information on the utilization of capital stock within the iron and steel industry, in terms of tonnage of steel produced per cubic meter (blast furnace) or square meter (open hearth) of capacity, and in terms of the percentage of "idle time" for each process. Production per unit of capacity has climbed fairly steadily since 1960 , although a slowdown in recent years and a slight decline in the rate of utilization indicates how closely the performance of this capital stock is related to that of industry as a whole.

\section{REFERRENCES}

CMEA (various years) Statisticheskij ejegodnick stran-chlenov SEV (Statistical Yearbook of the CMEA Economies). Finansy i Statistica, Moscow.

ECE (1983) Strategy for Energy Use in the fron and Steel Industry. United Nations, New York.

Egorichev, A. (1984) Povyshenie effectivnosti ispolsovaniya energoresoursov v chernoi metallurgii (Efficiency of energy resources utilization in the iron and steel industry). Promyshlennaje Energetika, 07.

Foreign Trade (various years) Vheshnaya Torgovlja SSSR (USSR Foreign Trade). Finansy i Statistica, Moscow.

Gladyshevski, A., Belous, G., and Lavrenov, N. (1980) Problemy modelirovanija i prognozirovanija osnovnyh potokov chernyh metallov (Modeling and forecasting of the demand for finished steel products). In: Modelirovanie structury proizvodstua (Modeling of Production Structure). CEMI, Moscow (in Russian).

Kogan, Y. (1984) Elektroenergija v systeme proizvodstvennych resoursov (Electricity in the system of productive resources). Voprosi Ekconomiti, 4 (in Russian).

Ksenofontov, M. (1980) Modelirovanie formirovanija narodnokhozajstvennoj potrebnosti v toplivno-energeticheskich resoursach (Modeling of energy demand). In: Modelirovarie structury proizvodstva (Hodeling of Production Structure). CEMI, Moscow (in Russian).

Lavrenov, N. (1976) Ispolzovanie materialnyh balansov dlya postroenia dynamicki ukrupnennych pokazatelej meszltraslevyh svyazej chernoij metalurgii (Use of material balances for iron and steel industry modeling). In: Model meszotraslevyh vzaineodejsbvig (Hodel of Interindustry interactions). CEMI, Moscow (in Russian).

Narkhoz (various years) Narodnoye Khozjastvo SSSR (Statistical Yearbook of the USSR Economy). Finansy i Statistica, Moscow.

Pavlenko, V. and Tichomirov, A (1983) Modelirovanie dynamici toplivnoenergopotrebleniya $v$ chemoi metallurgii SSSR (Modeling of energy use in the USSR iron and steel industry). EMM, 19(4)(in Russian).

Smyshlyaev, A. (1982) Hodel of Interindustry Interactions as a System of Simultaneous Equations. Working Paper WP-82-28. International Institute for Applied Systems Analysis, Laxenburg, Austria.

Smyshlyaev, A and Pavlenko, V. (1981) Prognozirovanie struktury proizvodstva v chernoi metallurgii SSSR (Forecasting of the USSR iron and steel industry production structure). EMM, 17(3) (in Russian).

UN (various years) Quorterly Bulletin of fron and Steel Production. United Nations, New York.

Yaremenko, Y. (1881) Structurnye izmenenija v socialisticheskoj ekonomike (Structural Changes in a Socialist Economy). Mysl., Moscow (in Russian). 